\title{
USING SCRABBLE FOR LEARNING ENGLISH VOCABULARY AT MAN 2 KUANTAN SINGINGI \\ Sri Chairani
}

Islamic University of Kuantan Singingi, Riau, Indonesia

E-mail: srichairani1@gmail.com

Received: 2021-06-11

Accepted: 2021-06-19

\begin{abstract}
Reading, writing, listening, and speaking are four language skills that need to be mastered. The skills include language components: vocabulary, grammar, spelling, and pronounciation. Among the language components, vocabulary become potential to be improved with various medias of learning since vocabulary is one of the main factors to understand a language. Therefore, this research is determined to find out the impacts of using scrabble for learning English vocabulary at Kampung Inggris Pare AEC MAN 2 Kuantan Singingi. The scrabble game can help the students understand vocabulary easily. They have to arrange words using the given letter tiles onto the board game. The method used to do this analysis is qualitative research method due to its suitability for generating the data properly. The result of this research shows that scrabble does not only improve the motivation and interest, but also students' vocabulary mastery in term of spelling, pronouncing and memorizing of vocabulary, and also gives much contribution to their speaking ability as well. The class can be more enjoyable, and furthermore, such class can make the students enthusiastic and confident to speak English.
\end{abstract}

Keywords: Scrabble, Vocabulary, Impact of Scrabble

\section{Introduction}

Language is a means of communication. It means that language is a medium for humans to communicate, socialize and interact with others. English is a medium of communication in many countries in the world as English is one of international languages. Many people in Indonesia want to learn English because it becomes the second language after Indonesian language. There are many places of English course where English can be learned. One of them is Kampung Inggris Pare AEC MAN 2 Kuantan Singingi, running Arabic and English Courses. The learning place is different from another in Kuantan Singingi. The place is like a camp using English teaching system of Kampung Inggris Pare, Kediri-East Java.

Mastery of vocabulary is an important thing in communication either in speaking or writing skills. Besides speaking and writing skills, there are two more language skills to be mastered in communicating ability, they are listening and reading. Vocabulary is necessary to gain those skills. Those skills include language components, i.e. vocabulary, grammar, spelling and pronounciation. And vocabulary is one of the most important components to gain communication ability. Learning vocabulary is as pedagogical implication in all things concerning language instruction and learners need to know a lot about more words to understand the instruction well. In essence, learners need a relatively large vocabulary to function in a language. Function in language means the meaning of vocabulary or word. The 
ways to convey the meaning of word are: 1)definition or explanation, 2)demonstration or gesture, 3)synonym or antonym, 4)giving examples, and 5) defining in situational context (Chachon-Beltran et.al, 2010: 38-39).

In Kampung Inggris Pare AEC Man 2 Kuantan Singingi, the students learn many things such as vocabulary, grammar, pronounciation, expressions, speaking, listening, storytelling, etc. In learning process, the learners will get language skills, especially speaking. To get the skill, many process can been done, and one of them is learning vocabulary by using scrabble media as one of the tools. Using media in learning process will get many profits. They are; 1 ) the learning will be interesting for the students and it gives student motivation; 2) the material of learning will be clearer and easier to understand, and probably the students can reach the goal of the learning; and 3) the students have more studying activities because they do not only listen to the explanation of the teachers, but also they can observe, execute, demonstrate, etc. In line with the above opinion, Luisa (2020: 156) states that media of learning English as a way of enhancing language acquisition providing a natural environment for sufficient exposure in the target language. Target language can be assumed as the goal of learning. Then, Glaveanu (2011) argues that educators can make vocabulary more engaging and easier to learn through the use of games. Learning vocabulary by using scrabble media is influential for learners. It makes them active, and they feel fun because they are studying by playing games. It is like what Bukzpan (2012) explains about Scrabble for Scramble. He says that scrabble is a collection of word game that has the ability to trancend the 225 squares of its board-that offer the chance to take what is learned ostensibly to beat one's opponent. It is a game unlike chess or backgammon, poker or dominos, as scrabble can be one of the recommended games for vocabulary learning.

An English tutor of Kampung Inggris Pare AEC MAN 2 Kuantan Singingi, Banyas Ambara, says that it is very important to learn vocabulary because it is one of important aspects in speaking. He wants the learners to be able to speak English and to master the skills of language as the vision of Kampung Inggris Pare AEC MAN 2 Kuantan Singingi. It takes after the opinion of Brown (2010: 172) that explains: first, speaking vocabulary is adequate to express anything as the most elementary needs; second, having sufficient vocabulary could express oneself simply with some circumlocutions; and third, ability to speak the language with sufficient vocabulary could be used to practicipate effectively in most formal and informal conversation on practical, social, and professional topics. The teaching system for learning English vocabulary is designed to encourage the learners to memorize vocabulary so that the learners have speaking ability. The students feel fun to study by using scrabble game and they also feel enthusiastic because they can follow scrabble game tournament for the Milad of MAN 2 event and SEO (Sumatera English Olympic) UNRI which is conducted every year.

With the above points in mind, using scrabble for learning English vocabulary at Kampung Inggris Pare AEC MAN 2 Kuantan Singingi is one of the important aspects of learning; this has been brought up into a reasearch being done in that area, but its impacts have not been known yet. Learning vocabulary by using scrabble as well as its impacts to the learners' ability can provide lots of advantages not only for English learners but also for the teachers as well. Scrabble game gives positive impact for the students' vocabulary mastery; meanwhile, it can give information for English teacher or other tutor to use scrabble game as one of media of teaching English vocabulary. 


\section{Literature Review}

\subsection{Vocabulary}

Schmitt (2010: 3-4) states that vocabulary is an important component of language use. Learning vocabulary is an esssential part of mastering a second language. The importance of vocabulary is highlighted by the often-repeated observation that learners carry around dictionaries and not grammar books. As quoted in Schmitt (2010: 3-4), "without grammar very little can be conveyed, without vocabulary nothing can be conveyed." This indicates that vocabulary is really important of language use. Vocabulary is all about word, when we use language we use words all the time, thousands of them. If we know a language well, we know how to write its word and how to say its word (Mc.Charty et.al, 2010: 1).

Grambs (as cited in Fahrizal, 2019) says, "Vocabulary is a list of words usually defined and alphabetized as a dictionary or specialized glossary". It can be concluded that vocabulary is a list of words that are arranged into a single meaning and contained in the dictionary. Meanwhile, Harmer (as cited in Fahrizal, 2019) says, "Vocabulary is more than merely a list of words. The words express meaning but meanings are a slippery concept. Some words may appear to be simple to refer to one thing and therefore easy to teach, but some others may also be difficult to teach because their meanings may change depending on the contexts".

\subsection{Types of Vocabulary}

There are two types of vocabulary described by Ellis and Tomlinson (cited in Akar, 2010: 16-17) :

- Receptive/Passive Vocabulary

A Learner's passive vocabulary consists of the total number of lexical items which he can understand correctly, and it is one of the teacher's aim to increase gradually the size of the learner's passive vocabulary so that he can eventually read and understand ungraded book and he can listen with good understanding to people speaking on a wide range of topics as well.

- Productive/Active Vocabulary

A learner's active vocabulary consists of the total number of lexical items which he can accurately use in speech and writing.

Meanwhile Nation (2013:46-47) describes the types of vocabulary as follows :

- Receptive/Passive Vocabulary

Carries the idea from others through listening or reading and trying to comprehend it.

- Productive/Active Vocabulary

Carries the idea that we produce by speaking and writing to convey messages to others.

\subsection{Scrabble}

Scrabble is to train the students arranging the word, sentence, or discourse and can improve the vocabulary mastery in vocabulary learning process. Games are helpful because they can make students feel that certain words are important and necessary because without those words the object of the game cannot be achieved (Akar, 2010: 53). It seems that using scrabble game can encourage the students to memorize the vocabulary.

The scrabble game can help the students to understand vocabulary easily. They have to arrange words using the given letter tiles onto the board game. Scrabble game includes the old game, so it needs to know the history of scrabble. The history of scrabble was originally called Criss Cross, the game, which was based on the crossword puzzle and anagrams, and was developed by Alfred M. Butts, an architect, in 1931. It was redesigned, renamed as 
Scrabble, and marketed by James Brunot in 1948. It was first sold in Great Britain in 1954. Scrabble was later produced in many foreign languages, Braille, and magnetic editions and continued to be one of the leading board-and-tile games in the United States. Tournaments have been held in the United States since 1973. In 2005 Scrabulous, an unauthorized online version of Scrabble, was released, and two years later it debuted (Bukszpan, 2012).

The games can also be practiced with vocabulary, grammatical patterns, and interaction skills in a learner-center, low-stress environment. The games provide opportunities to talk informally and to think creative (Mc.Caughey et.al. 2013). That is why the teachers have reasons to apply game in class in learning. By using game, the learning process becomes more dynamic and enjoyable.

\subsection{Strategy of Scrabble Game}

Strategy of scrabble game is cooperative. It is a cooperation game which includes two to four players to work together to arrange the words or sentences. To play scrabble game needs rules. The scrabble game is played with different rules in different countries or regions. The general rules of playing scrabble game are as follows :

1) All players determine the subject in the game;

2) They place every tile, facing to down and stirring it;

3) They determine the first player;

4) Every player takes 8 tiles;

5) The first player creates a word on the board game;

6) The player uses time to create the word;

7) The player takes the new tiles as needed;

8) Every player can use the empty tiles to change the letter he wants;

9) Every player can use his turn to change the tiles;

10) The game is going on until all of the tiles are finished;

11) The score can be assisted by totaling the letter's score that has already been on the board.

\subsection{Impact of Using Scrabble for Learning English Vocabulary}

Scrabble media is a part of cooperative learning model. Scrabble game is a suitable way of vocabulary learning. Scrabble game involves learners in thinking about the words. Using this game for learning English vocabulary allows learners to remember the target words more easily. Learning vocabulary is a hard work so the learners are required to understand, to produce and to manipulate the target words. Games help and encourage many learners to learn target language more easily. They also help teachers create contexts in which the target words are useful and meaningful. They also bring fun for students; thus, games help them learn and retain new words more quickly. In other words, game-based learning can create a meaningful context for language learning process (Derakshan, 2015).

Many impacts of using game in learning vocabulary are based on findings of some researchers. Here are some findings of the impact of using game in learning vocabulary:

1) Donmus (2010): The value of educational games has been increasing in language education since they help making language entertaining, and the students continuously interacting in Facebook benefited from educational games for their learning; it can motivate and help students construct their own learning. 
2) Kalaycioglu (2011): games are fun for the children and they include interaction, physical and cognitive activity, socialization, competition, and cooperation. They learn individual and group work; their motivation and interest increase in games.

3) Gillespie in Kalacioglu (2011): educational games are used frequently due to their benefits. They give students responsibility and the opportunity of being active physically and mentally. They are student-centered rather than teacher-centered, fun to play in the formal academic process. In addition, students gain or develop many skills such as taking turns, working individually and working with others as a team toward a common goal.

Bearing the findings above in mind, those show the impacts of game (i.e. scrabble) for learning vocabulary, i.e. 1) giving motivation, 2) bringing about positive attitude, 3) creating friendly and valuable condition, 3) creating cooperation, 4) improving communicative skill, 5) entertaining, 6) continuously interacting, 7) thinking critically, 8) easily remembering, 9) fun and interesting, 10) building responsibilty and opportunity to be active physically and mentally. As verified by Philips in Sadewo (2016), there are many effects for learners: atmosphere of the class, attitude of the teacher, and organization of the lesson.

\section{Research Method}

This research uses qualitative method and focuses on a certain phenomenon at Kampung Inggris Pare AEC MAN 2 Kuantan Singingi environment. The purpose of qualitative research is to describe and understand social phenomena in terms of the meaning people bring to them. The methods produce rich, descriptive data that need to be interpreted through the identification and coding of themes and categories leading to findings that can contribute to theoretical knowledge and practical use. This research does not give the test to the objects of the research, as observation, interview, and documentation are applied. There are three approaches which are conducted in this research. The first is direct observation of the class condition including the tutor and the students of Kampung Inggris Pare AEC MAN 2 Kuantan Singingi. The second is interview to the English tutor of Kampung Inggris Pare AEC MAN 2 Kuantan Singingi. The last is documentation.

\section{Results and Discussion}

\subsection{The Use of Scrabble Game in Learning English Vocabulary}

From the result of observation and interview with several students, eighteen from thirty students never play scrabble game. Since they join English camp, scrabble game is a new experience for them in English learning, especially vocabulary mastery. So, using scrabble game for learning English vocabulary attract them. They become active when studying English using scrabble game, and they also assume that scrabble game help them improve their motivation and interest in learning English. The use of scrabble game in learning English vocabulary can improve the students' vocabulary mastery in term of spelling, pronouncing and memorizing of vocabulary, and possiblity to improve their speaking ability. Almost all of the students have the same answer from questions list in interviewing the students. This statement is strengthened by the interview's answer from the tutor and the students:

Tutor : "When I teach English to improve vocabulary by using scrabble game, the students feel enthusiastic and enjoy the class, their achievement of study is increasing, and they become more confident to speak English". 
Student 1: "Using scrabble game in learning English vocabulary is good. The difficult vocabulary could be memorized because every new word will be repeated by the tutor until the students remember it".

Student 2: "Learning English vocabulary by using scrabble game is very interesting for me because I know the new words and how to spell and pronounce them".

Student 3: "Scrabble game? Wow, I like it..... It motivates me to be able speak English because".

Referring to the interview and observation conducted by the researcher, the use of scrabble game in learning English vocabulary for the students is based on guidance of tutor. The total numbers of the students at Kampung Inggris Pare AEC MAN 2 Kuantan Singingi are thirty. The students are divided into two classes; each class consists of fifteen students. Before starting the game, the tutor gives explanation about the rules and requirements to play scrabble related to the topic of the lesson. Then, the tutor divides the fifteen students into three groups in which each group consists of 5 students. Each group has four students to work in pairs and 1 student to note the score. Lastly, the tutor discusses the meanings of the words with the students and ask the students to write down every single word in their own group.

\subsection{The Impacts of Using Scrabble Game for Learning English Vocabulary}

The researcher obtains the result by conducting observation and interview. Based on the data, scrabble game gives good impacts for the students in learning English vocabulary. There are many impacts of using scrabble game for learning English vocabulary for the students at Kampung Inggris Pare AEC MAN 2 Kuantan Singingi. They are enjoyable, enthusiastic, confident, interesting, motivating, and improving.

From the observation and interview, it is known that scrabble game is successful in making the students feel enjoyable to learn vocabulary.

The students are enthusiastic to learn vocabulary as they can follow the SEO tournament. Here are the statements of several students about the explanations above:

Student 1 : "I am really interested in learning vocabulary through scrabble game".

Student 2 : "wow....scrabble game make the class interesting, I keep waiting impatiently to learn vocabulary".

Student 3 : "I have never played scrabble game before, it is new for me. So, I feel excited to learn vocabulary".

Those statements verify that scrabble game gives good impacts to the students at Kampung Inggris Pare AEC MAN 2 Kuantan Singingi. From interview and observation it is seen that some students have never studied or played scrabble game; then, they have interest in learning vocabulary. The researcher believes that learning English vocabulary by using scrabble game can improve vocabulary mastery of the students at Kampung Inggris Pare AEC MAN 2 Kuantan Singingi and will enable them to master the four language skills such as reading, listening, speaking, and writing. Thus, they can speak English fluently and confidently.

\section{Conclusion}

Based on the results, it can be concluded that using scrabble for learning English vocabulary at Kampung Inggris Pare AEC MAN 2 Kuantan Singingi has four impacts for the 
students. First, the game can improve the motivation and interest of the students. Second, it can improve the students' vocabulary mastery in term of spelling, pronouncing and memorizing, and also improve their speaking ability. Third, the class becomes more enjoyable. And the last, it can make the students enthusiastic and more confident to speak English. So, scrabble game gives benefits for the students' vocabulary mastery because vocabulary can help students improve speaking ability.

\section{ACKNOWLEDGEMENT}

Assalamu'alaikum Warahmatullahi Wabarakatuh.

Alhamdulillah, Alhamdulillah, The Most Gracious and The Most Merciful, praise be to Allah SWT and blessing to our prophet Muhammad SAW, who has brought us from darkness into brightness.

This research is entitled "Using Scrabble for Learning English Vocabulary at MAN 2 Kuantan Singingi." In writing this research, the researcher is helped many people. Firstly, the reseacher would like to express gratefulness to her beloved husband Taufiq Gunawan Lubis, SE for love, pray, support, attention, and motivation during the writing process. Secondly, the researcher would also like to thank the founder of Kampung Inggris Pare AEC MAN 2 Kuantan Singingi Drs. Zulkifli, M.Pd and Seprion, S. Ag., M.Pd and the tutor Banyas Ambara, S.Pd who helps the researcher conduct the research at that English Camp. Finally, the researcher fully thanks everyone who gives support in finishing this research. The words are never enough to express gratefulness, only praise to Allah SWT for blessing and mercy. The researcher hopes this research will be useful for everyone, particularly for the teachers, students and other researchers.

Wassalamu'alaikum Warahmatullahi Wabarakatuh.

\section{Reference}

Akar, Nurgun. (2010). Teaching Vocabulary Bridging the Gap between Theory and Practice. Ankara: EDM Ltd.

Brown, H, Douglas. (2010). Principle of Language Learning and Teaching. Pearson: Longman.

Bukszpan, David \& Hopkins, Dave. (2012). Is that a word from AA to ZZZ, the weird and wonderful language of scrabble. Chronicle books.

Chacon-Beltran, R., et al. (2010). Insight into Non-native Vocabulary Teaching and Learning. Canada: Multilingual Matters.

Derakhshan, Ali. (2015). The effects of Using Games on English Vocabulary Learning. Journal of Applied Linguistic and Language Research. Volume 2, issue 3, pp. 39-47.

Donmus,V.(2010). The use of Social Networks in Educational Computer-Game Based Foreign Language Learning. Social and Behavioral Sciences, 9, 1497-1503.

Fahrizal, Muhammad. 2019. The Effect of Scramble Game on The Seven Grade Students' Vocabulary Mastery At SMP PAB 19 Manunggal. Medan: UMSU.

Glaveanu, vlad pete., et.al. (2016). Creativity-a New Vocabulary. London: Palgrave Macmillan.

Kalaycioglu, H. (2011). The Effect of Picture Vocabulary Games and Gender on Four Year-Old Children's English vocabulary Performance: An Experimental Investigation. Unpublished MA thesis. Ankara: The Middle East Technical University.

Luisa, Maria Carrió-Pastor. (2020). Internationalising Learning in Higher Education. The Challenges of English as a Medium of Instruction. London: Palgrave macmilan. 
Mc. Carthy, Michael., et al. (2010). Vocabulary Matrix. Understanding, Learning, Teaching. London: Heinle Cengace Learning.

Nation, I. S. P. (2013). Learning Vocabulary in Another Language. Cambridge: Cambridge University press.

Sadewo, G. P. (2016). Using Scrabble Game to Improve the 10th Grade Students' Vocabulary Mastery at SMA N 2 Purwerejo. Yogyakarta: Sanata Darma University.

Schmitt, Nobert. (2010). Researching Vocabulary a Vocabulary Research Manual. New York: Palgrave Macmilan. 